\title{
ECOTOXICOLOGICAL EFFECTS OF BIODIESEL IN THE SOIL
}

\author{
Małgorzata Hawrot-Paw ${ }^{1}$, Monika Izwikow ${ }^{1}$ \\ 1 Department of Microbiology and Environmental Microbiology, West Pomeranian University of Szczecin, \\ Słowackiego 17, 71-434 Szczecin, Poland, e-mail: malgorzata.hawrot-paw@zut.edu.pl
}

Received: 2015.08.14

Accepted: 2015.10 .06

Published: 2015.11.10

\begin{abstract}
The paper analysed the toxic effect of the presence of biodiesel in the soil. The study involved tests with microorganisms that evaluated changes in their number and activity, and phytotoxicity tests with garden cress (Lepidium sativum) and spring barley (Hordeum vulgare). Biodiesel produced in laboratory conditions and biofuel purchased at a petrol station were introduced to the soil. Two levels of contamination were used $-1 \%$ and $5 \%$ (per dry mass of the soil). Based on the results, it was discovered that biofuels both stimulated and reduced the number and activity of microorganisms. The changes observed depended on the type of biofuel and, most often, on its dose. Laboratory biodiesel exhibited more toxic effects, especially for actinobacteria and fungi. The tested plants showed diverse sensitivity to the presence of biodiesel. Given the determined value of the germination index, laboratory biodiesel was more toxic to spring barley and commercial biofuel to garden cress. In both cases, toxicity increased with an increase in the amount of biofuel.
\end{abstract}

Keywords: biodiesel, soil, microorganisms, microbial biomass, bioassays, ecotoxicity.

\section{INTRODUCTION}

Petroleum fuels are a major source of environmental pollution [Head and Swannell 1999]. Petroleum hydrocarbons modify the physico-chemical, biochemical, and microbiological properties of soils [Wyszkowska and Kucharski 2000, Merk1 et al. 2005, Agbogidi et al. 2007, Tejada et al. 2008], adversely affect plants and also cause contamination of groundwater [Siddiqui and Adams 2002, Serrano et al. 2009]. Biofuels are an alternative to traditional fuels. The intensification of efforts to increase their share as an energy source is mainly caused by economic reasons (increasing prices of crude oil and its derivatives, difficulties with supplies or depletion of resources) as well as environmental ones (traditional fuels' negative impact on the environment).

The most important biofuels are, among others, bioethanol, methanol, methane and biodiesel produced by transesterification of vegetable oils or animal fat. Biodiesel can be used as a fuel itself (B100) or a bio-component in a mixture with diesel oil. The use of biodiesel reduces emissions of hydrocarbons, carbon monoxide and volatile organic compounds [Ramadhas et al. 2005, Usta 2005, Fernando et al. 2006, Murugesan et al. 2009]. However, the results of analysing the biological effects related to the presence of biodiesel in the environment are ambiguous. Experiments conducted by Peterson and Reece [1994] indicate that it is much less harmful to the species of Daphnia magna than conventional fuel. According to Khan et al. [2007], the increase of biodiesel content in diesel fuel reduces mortality of these crustaceans. On the other hand, Bünger et al. [2000] noted a four-times higher toxicity of biodiesel exhaust gases, compared to conventional fuel. Tamada et al. [2012] have observed high toxicity of biodiesel and its metabolites to earthworms of the species Eisenia andrei. Kooter et al. [2011] revealed a significant higher relative cytotoxicity of the biodiesel compared to diesel fuel. Liu et al. [2009] compared extracts of gaseous emissions from diesel fuel and the biodiesel blend - in the Microtox test B10 had a higher acute toxicity and cytotoxicity than diesel. The impact of biodiesel on the microorgan- 
isms whose activity is extremely important for its proper functioning, is ambiguous [Winding et al. 2005]. Biofuel can increase respiration proportionally to the increase of its amount, stimulate, or restrict dehydrogenase activity and microbial biomass content [Lapinskiene et al. 2006, Hawrot-Paw and Martynus 2011]. The differences in test results regarding toxicity induced by biodiesel may arise, among other reasons, from the different chemical composition of biofuels, which depends on the substrate from which they were produced. Even the particular batch of fuel can matter [Bluhm et al. 2012].

The use of biological tests for the toxicity of biofuels can not only allow the detection of contamination, but also provides information about the possibility of restoring soils their function as a living environment for organisms. The aim of this study was to assess the changes caused by the presence of biodiesel in the soil. We analysed the reaction of soil microflora based on the number and activity of microorganisms and plants (phytotoxicity tests).

\section{MATERIALS AND METHODS}

\section{Materials}

The study was conducted on loamy sand. The material was collected from a depth of $0-15 \mathrm{~cm}$ from the level of agricultural-humic soil in the Experimental Station in Lipnik, belonging to the West Pomeranian University of Technology in Szczecin. The study used biodiesel prepared in the laboratory in the process of methanol transesterification of rapeseed oil (BDI) and commercial biodiesel bought at petrol station (BDII). In the phytotoxicity test, as bioindicators of contamination, spring barley Hordeum vulgare and garden cress Lepidium sativum were used.

\section{Methods}

Based on actual moisture, soil samples were brought to $50 \%$ of their capillary water capacity. This moisture was maintained during the entire experiment and any losses were refilled with distilled water. The fuel was introduced into the soil in the amount of $1 \%$ and $5 \%$ (per dry mass of the soil), leaving one object uncontaminated as a control sample (C). Soil samples were incubated at temp. $20 \pm 1{ }^{\circ} \mathrm{C}$ for four weeks. The ecotoxicological tests, including microbiological analysis and phytotoxicity tests, were performed on the 28th day of the studies.

\section{Ecotoxicological tests}

The microbiological analyses involved evaluating changes in the number of bacteria, actinobacteria, and fungi, as well as the biomass content of living organisms. The number was determined by plating dilutions of soil using media suitable for different groups of microorganisms - bacteria after three days of incubation on Bunt and Rovira's medium [1955], for actinobacteria after seven days on Cyganow and Žukov's medium [1964] and for fungi after five days on Martin's medium [1950] in $25^{\circ} \mathrm{C}$. The results were expressed as CFU (colony forming units) per $1 \mathrm{~g}$ dry mass of the soil. The content of the biomass was estimated by the SIR method according to Anderson and Domsch [1978]. All microbiological analyses were performed in three repetitions.

In the phytotoxicity test, as bioindicators of contamination, spring barley Hordeum vulgare and garden cress Lepidium sativum were used. In the experiment, the modified test of germination / root elongation [Włodkowic and Tomaszewska 2003] was employed, calculating the germination index according to the formula proposed by Barbero et al. [2001]:

$$
\% G I=\frac{100 \cdot\left(G_{S} \cdot L_{S}\right)}{\left(G_{C} \cdot L_{C}\right)}
$$

where: $G$ and $G$ is the number of seeds that germinated in the research sample and in the controls sample,

$L$ and $L$ is the length of roots in the reséarch sample and in the controls sample.

Phytotoxicity tests were performed in three repetitions, using 10 seeds in each repetition.

\section{Statistical analysis}

The analysis of variance (ANOVA) and the Newman-Keuls test at the $P<0.05$ level were used to analysed the experimental results. Statistical calculation were carried out using Statistica 10.0 program (StatSoft, Poland).

\section{RESULTS AND DISCUSION}

The soil has the ability to renew its resources, which are essential to the growth and development of plants and other organisms, among other 
reasons, due to the presence of microorganisms [Russel 2005]. All factors that adversely affect microorganisms can also have a negative impact on the quality of the soil.

Changes in the number and activity of microorganisms under the influence of biodiesel are shown in Figure 1(A-D). Statistical analysis showed a significant effect of the type of biofuel and its amount on the numbers of actinobacteria, fungi, and biomass content. In the case of bacteria, regardless of the amount, biofuels stimulated their growth compared to the control sample. Values shown in BDI and BDII were approx. $20-40 \%$ higher than in control samples, but these differences were not statistically significant. Biofuels used in the study negatively affected actinobacteria, which, due to significant enzymatic activity of these microorganisms, can cause a reduction in the rate of mineralization of the soil's organic matter [Paul and Clark 2000]. A signifi- cant reduction in their numbers, as the amount of biodiesel increased, was observed mainly in the BDI sample. Significant changes were also found after the introduction of commercial biodiesel into the soil. However, the degree of inhibition in this case was lower (up to $65-69 \%$ with over $90 \%$ in $\mathrm{BDI}_{5}$ ). Biodiesel prepared in the laboratory inhibited fungal growth, and soil where commercial biofuel was introduced revealed a significant stimulation, in particular in BDII 5 . The growth in the number of fungi in the presence of biodiesel has also been reported in previous studies [Hawrot-Paw 2011].

According to Gil-Sotres et al. [2005], biomass is an important indicator of the quality of soils, including those contaminated with fuels [Brohon et al. 2001]. The content of biomass of living organisms in the soil contaminated by hydrocarbons changed depending on the kind of biofuel and its dosage. At a concentration of $1 \%$, biodiesel ad-
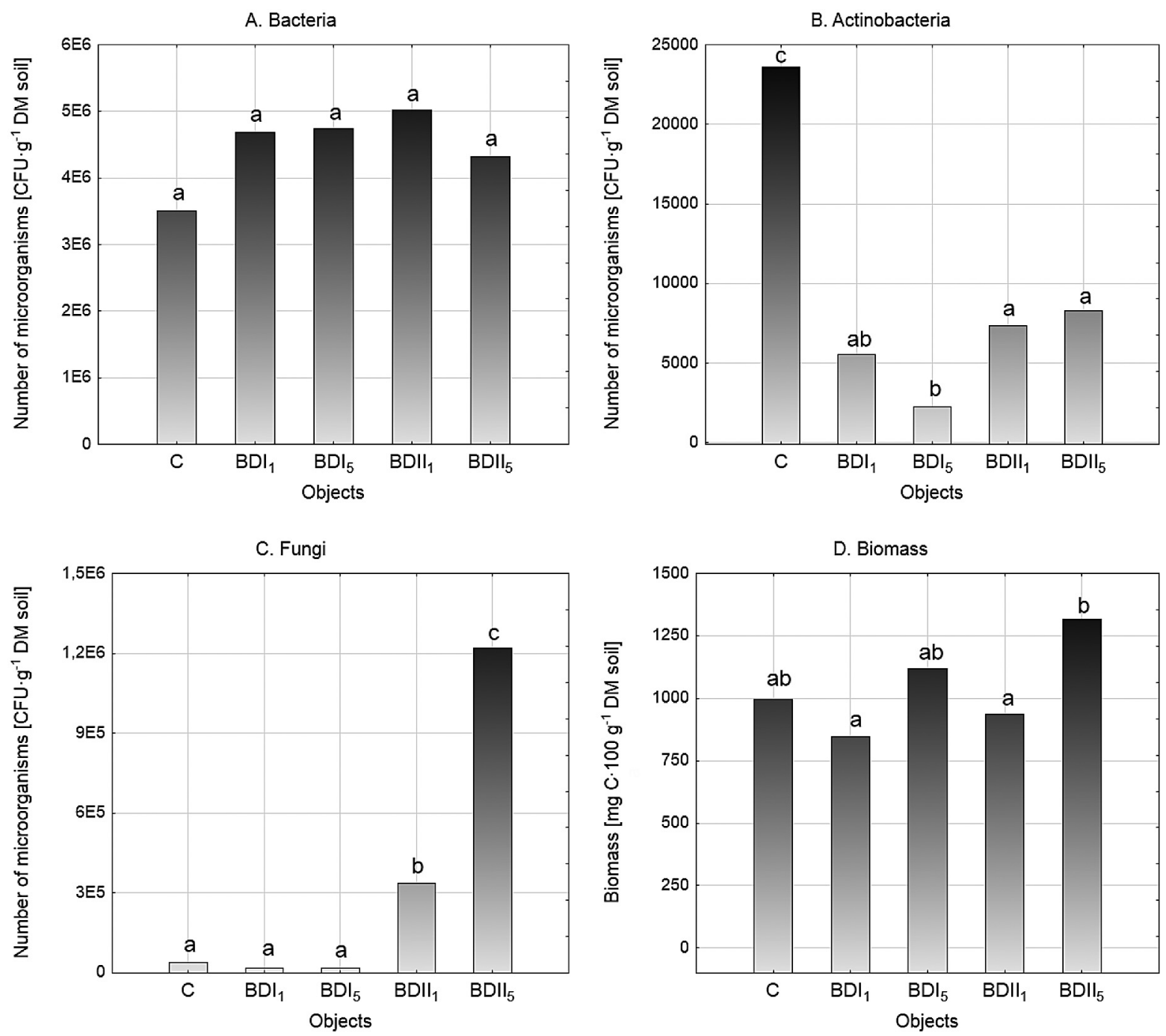

Figure 1. The number of microorganisms and the biomass content in biodiesel contaminated soil (mean over each columns not marked with the same letter is significantly different at $P<0.05$ ) 
Table 1. The germination index value in particular experience objects

\begin{tabular}{|l|c|c|c|c|c|}
\hline \multirow{2}{*}{ Plants } & \multicolumn{5}{|c|}{ Germination index [GI\%] } \\
\cline { 2 - 6 } & $\mathrm{C}$ & $\mathrm{BDI}_{1}$ & $\mathrm{BDI}_{5}$ & BDII $_{1}$ & BDII $_{5}$ \\
\hline Spring barley (Hordeum vulgare L.) & 100 & 69 & 43 & 123 & 67 \\
\hline Garden cress (Lepidium sativum L.) & 100 & 121 & 68 & 82 & 69 \\
\hline
\end{tabular}

versely affected both BDI and BDII, and in the presence of $5 \%$ contamination, the biomass content in soil contaminated with commercial fuel increased compared to the control sample. In the experiments carried out by Lapinskiene et al. [2006] biodiesel even in a concentration of $12 \%$, did not adversely affect the activity of the microorganisms. In previous studies of Hawrot-Paw et al. [2010] a 10\% biodiesel dose caused a reduction of the biomass content below the control values (inhibition persisted for 112 days of the experiment), while in the soil contaminated with $5 \%$ biodiesel, the content of the biomass during incubation varied. In these experiments, we used a biofuel obtained directly from the manufacturer.

In evaluating the phytotoxic effect of biodiesel, we used seeds of garden cress (Lepidium sativum) and spring barley (Hordeum vulgare), which have successfully been used in the monitoring of the level of contamination of soils with conventional fuels [Maila and Cleote 2002, Kołwzan 2005, Hawrot-Paw 2011]. The specified germination index value, regardless of plant species or kind of biofuel, decreased with the increasing degree of contamination. Tamada et al. [2012] noted that commercial biodiesel showed far more phytotoxicity for the seeds of arugula (Eruca sativa) and lettuce (Lactuca sativa) than soybean oil used in their tests. In this study, garden cress was more sensitive to the presence of BDII biodiesel.

The toxicity of biodiesel may be generated by introducing chemical substances into it, whose aim is to prevent its oxidation [Tamada et al. 2012]. Synthetic antioxidants that may adversely affect various levels of biological life [Wiley 1994, Tseng and Tseng 1995, Aluyor et al. 2009], include, among others: butylated hydroxytoluene (BHT), butylated hydroxyanisole (BHA), tert-butylhydroquinone (TBHQ) and esters of gallic acid [Kruszewski et al. 2013]. Even pure vegetable oils may cause adverse changes, which result from waste products forming as a result of their biodegradation [Tamada et al. 2012]. Soil contaminated with biodiesel may include toxic methanol, which is formed by inverting the transesterification re- action and is present in its water-soluble fraction [Leite et al. 2011, da Cruz et al. 2012].

\section{CONCLUSIONS}

Fuel elements can be a valuable source of carbon and energy for microorganisms, necessary for their growth and development, but they can also be toxic to the same microorganisms. Antioxidants are added to vegetable oils, and in the production of biodiesel stabilizers, depressants, or antimicrobial agents, which may adversely affect some organisms, are also added. Biodiesel produced in laboratory conditions in most cases exerted more negative influence than commercial biofuel towards, for example, actinobacteria or fungi. These results may indicate that the response of test organisms used in the study may result directly from the different chemical composition of biofuels or result indirectly from physico-chemical changes caused by biodiesel in the soil. These factors may have a significant impact on phytotoxicity of biodiesel, as indicated by the diverse reaction of garden cress (Lepidium sativum) and spring barley (Hordeum vulgare). In the context of the presented results of the ecotoxicological effects of the biofuels, the related research should be continued.

\section{REFERENCES}

1. Agbogidi O.M., Eruotor P.G., Akparobi S.O., Nnaji G.U. 2007. Evaluation of crude oil contaminated soil on the mineral nutrient elements of maize ( $\mathrm{Zea}$ mays L.). J. Agronomy, 6(1), 188-193.

2. Aluyor, E., Oboh I. Okieimen C. 2009. The effect of tertiary butyl hydroquinone on the biodegradability of palm olein. Leonardo El. J. Pract. Technol., 14, 47-56.

3. Anderson J.P.E., Domsch K.H. 1978. A physiological method for the quantitative measurement of microbial biomass in soil. Soil Biol. Biochem., 10, 215-221.

4. Barbero P., Beltrami M., Baudo R., Rossi D., 2001. 
Assessment of Lake Orta sediments phytotoxicity after the liming treatment. J. Limnol., 60(2), 269-276.

5. Bluhm K., Heger S., Seiler T.B., Hallare A.V., Scheafferb A., Hollert H. 2012. Toxicological and ecotoxicological potencies of biofuels used for the transport sector - a literature review. Energy Environ. Sci., 5, 7381-7392.

6. Brohon B., Delolme C., Gourdon R. 2001. Complementarity of bioassays and microbial activity measurements for the evaluation of hydrocarboncontaminated soils quality. Soil Biol. Biochem., 33, 883-891.

7. Bünger J., Krahl J., Baum K., Schröder O., Müller M., Westphal G., Ruhnau P., Schulz T.G., Hallier E., 2000. Cytotoxic and mutagenic effects, particle size and concentration analysis of diesel engine emission using biodiesel and petrol diesel as fuel. Arch. Toxicol., 74, 490-498.

8. Bunt J.S., Rovira A.D. 1955. Microbiological studies of some subantarctic soil. J. Soil Sci., 6(1), 119-128.

9. Cyganov V.A., Žukov R.A. 1964. Morfologobiochimiciskie osobennosti novowo vida actionomiceta. Mikrobiologija, 33(5), 863-869.

10. da Cruz A.C., Leite M.B., Rodrigues L.E., Nascimento I.A. 2012. Estimation of biodiesel cytotoxicity by using acid phosphatase as a biomarker of lysosomal integrity. Bull Environ Contam Toxicol., 89(2),219-24.

11. Fernando S., Hall Ch., Jha S. 2006. NO reduction from biodiesel fuels. Energy Fuels, 20(1), 376-382.

12. Gil-Sotres F., Trasar-Cepeda C., Leiros M.C., Seoane S. 2005. Different approaches to evaluating soil quality using biochemical properties. Soil Biol. Biochem., 37, 877-887.

13. Hawrot-Paw M. 2011. Biologiczna aktywność gleb zanieczyszczonych biodieslem oraz możliwości ich rekultywacji. Wyd. Zachodniopomorskiego Uniwersytetu Technologicznego w Szczecinie, Szczecin.

14. Hawrot-Paw M., Kamieniecka A, Smolik B. 2010. Biological activity of soil contaminated with biodiesel. Environ. Protect. Eng., 36(3), 87-93.

15. Hawrot-Paw M., Martynus M. 2011. The influence of diesel fuel and biodiesel on soils microbial biomass. Pol. J. Environ. Stud., 20(2), 503-507.

16. Head I.M., Swannell R.P.J. 1999. Bioremediation of petroleum hydrocarbon contaminants in marine habitats. Curr. Op. Biotech., 10, 234-239.

17. Kołwzan B. 2005. Bioremediacja gleb skażonych produktami naftowymi wraz $\mathrm{z}$ oceną ekotoksykologiczną. Wrocław, Oficyna Wydawn. Politechniki Wrocławskiej

18. Khan N., Warith M.A., Luk G., 2007. A comparison of acute toxicity of biodiesel, biodiesel blends, and diesel on aquatic organisms. J. Air Waste Manag. Assoc., 57, 286-296.

19. Kooter I.M., van Vught M.A.T.M., Jedynska A.D., Tromp P.C., Houtzager M.M.G., Verbeek R.P., Kadijk G., Mulderij M., Krul C.A.M.20111. Toxicological characterization of diesel engine emissions using biodiesel and a closed soot filter. Atmos. Environ., 5, 1574-1580.

20. Kruszewski B., Fąfara P., Ratusz K., Obiedziński M. 2013. Ocena pojemności przeciwutleniającej i stabilności oksydacyjnej wybranych olejów roślinnych. Zesz. Probl. Post. Nauk Roln., 572, 43-52.

21. Lapinskiene A., Martinkus P., Rebzdaite V. 2006. Eco-toxicological studies of diesel and biodiesel fuels in aerated soil. Environ. Pollut., 142, 432-437.

22. Leite M.B., de Araújo M.M., Nascimento I.A., da Cruz A.C., Pereira S.A., do Nascimento N.C. 2011. Toxicity of water-soluble fractions of biodiesel fuels derived from castor oil, palm oil, and waste cooking oil. Environ Toxicol Chem., 30(4), 893-897.

23. Liu Y.Y., Lin T.C., Wang Y.J., Ho, W.L. 2009. Carbonyl compounds and toxicity assessments of emissions from a diesel engine running on biodiesels. J. Air Waste Manage. Assoc., 59, 163-171.

24. Maila M.P., Cleote T.E. 2002. Germination of Lepidium sativum as a method to evaluate polycyclic aromatic hydrocarbons (PAHs) removal from contaminated soil. Int. Biodeter. Biodegrad., 50, 107-113.

25. Martin J.P. 1950. Use of acid rose bengale and streptomycin in the plate method for estimating soil fungi. Soil Sci., 6, 215-233.

26. Merkl N., Schultze-Kraft R., Infante C. 2005. Phytoremediation in the tropics - influence of heavy crude oil on root morphological characteristic of graminoids. Environ. Pollut., 138(1), 86-91.

27. Murugesan A., Umarani C., Subramanian R., Nedunchezhian N. 2009. Bio-diesel as an alternative fuel for diesel engines - A review. Ren. Sust. Energy Rev., 13, 653-662.

28. Paul E.A., Clark F.E. 2000. Mikrobiologia i biochemia gleb. Lublin, Wydaw. UMCS.

29. Peterson C., Reece D., 1994. Toxicology, biodegradability and environmental benefits of biodiesel. Department of Agricultural Engineering, University of Idaho.

30. Ramadhas A.S., Muraleedharan C., Jayaraj S. 2005. Performance and emission evaluation of a diesel engine fueled with methyl esters of rubber seed oil. Renew. Energ., 30(12), 1789-1800.

31. Russel S., 2005. Znaczenie badań enzymów w środowisku glebowym. Acta Agrophysica, Rozpr. Monogr., 3, 5-9.

32. Serrano A., Tejada M., Gallego M., Gonzalez J.L. 2009. Evaluation of soil biological activity after a 
diesel fuel spill. Sci. Total Environ., 407, 4056-4061.

33. Siddiqui S., Adams W.A. 2002. The fate of diesel hydrocarbons in soils and their effect on the germination of perennial ryegrass. Environ. Toxicol., 17, 49-62.

34. Tamada I.S, Montagnolli R.N., Lopes P.R.M., Bidoia E.D. 2012. Toxicological evaluation of vegetable oils and biodiesel in soil during the biodegradation process. Braz. J. Microbiol., 43(4), 1576-1581.

35. Tejada M., Gonzalez J.L., Hernandez M.T., Garcia C. 2008. Application of different organic amendments in a gasoline contaminated soil: effect on soil microbial properties. Biores. Technol., 99(8), 2872-2880.

36. Tseng H.-H., Tseng T.-Ch. 1995. Effects of butylated hydroxyanisole, butylated hydroxytoluene and tertiary butylhydroquinone on growth and luteoskyrin production by Penicillium islandicum. Mycopathologia, 129, 73-78.
37. Usta N. 2005. An experimental study on performance and exhaust emissions of a diesel engine fuelled with tobacco seed oil methyl ester. Energ. Convers. Manag., 46(15-16), 2373-2386.

38. Wiley R.C. 1994. Minimally processed refrigerated fruits and vegetables. New York, Chapman \& Hall.

39. Winding A., Hund-Rinke K., Rutgers M. 2005. The use of microorganisms in ecological soil classification and assessment concept. Ecotoxicol. Environ. Saf., 62, 230-248.

40. Włodkowic D., Tomaszewska B., 2003. Testy fitotoksyczności zanieczyszczeń ropopochodnych dla rzepaku (Brassica napus) i lucerny (Medicago sativa) $\mathrm{w}$ aspekcie potencjalnych zastosowań w fitoremediacji i biomonitoringu. IHAR, 24, 231-238.

41. Wyszkowska J., Kucharski J. 2000. Biochemical properties of soil contaminated by petrol. Pol. J. Environ. Stud., 9(6), 479-485. 